特 別

誨 演
海外銅鉱山開発の現状と展望*

\title{
Development Activities for Overseas Copper Resources
}

\author{
Keisuke MASUMOTO
}

\section{1. は じめに}

日本の非鉄金属企業は1973年秋の石油危機以降，円高 による諸コストの上昇および国内金属価格の崩壊によ り，国内鉱山を相次いで閉山し，企業体質の転換を余儀 なくされた。

海外の非鉄金属メジャーも䈌しい道を歩んだ。それは 1960年代の資源ナショナリズムによる鉱山の国営化, 1970年代の石油メジャーによる鉱山買収などの危機であ った。しかし，非鉄メジャ一は徹底した合理化，買収・ 合併, SX-EW 法の技術開発などで乗切り，1987年後半 からは高水準な国際銅価格と低コストかつ優良な大規模 鉱山の操業に支えられ，高収益を得るに至った。

国内鉱山の衰退につれて, 日本の非鉄金属企業は鉱石 を海外から翰入して製錬するカスタムスメルターの道を 選んだ。しかし，近年の急激な円高はその採算性を低下 させ，高水準の金属価格は買鉱競争の激化と買鉱条件の 悪化を招いている。

この円高環境下での生残り策は, 優良な海外鉱山開発 への投資による低コスト自山鉱確保による鉱山・製鏳一 体化での収益改善である。これは製錬業の維持, 鉱石の 安定供給源の確保, 加えて, 鉱山技術（者）の維持（確 保）や新技術開発にも関連してくる。

本論では，主として自由世界の銅資源を中心に，日本 の海外鉱山開発の現状および問題点, 海外の非鉄メジ ャ一の動向およびその戦略を概観し，日本非鉄金属企業 が海外鉱山開発で今後取るべき方向を述べてみたい。

\section{2. 国内非鉄金属鉱山の現状と供給構造 10)}

1994年 4 月 1 日現在, 国内非鉄金属鉱山は 12 鉱山で, 従業員数は約 1,400 人である。銅釷山はなく，従業員 100

*平成 6 年11月10日本会第93回例会において発表

**三菱マテリアル株式会社

平成 6 年 9 月 21 日受理
人以上の非鉄金属鉱山は豊羽（鉛亜鉛）, 神岡（鉛要鉛） および菱杊（金銀）の 3 山のみで，その他の鉱山も主と して金銀鉱山である。

国内鉱山の使命は，(1)鉱石の安定供給源，(2)鉱山技術 の温存, (3)地域経済振興にあるが, 高品位金銀鉱山以外 の非鉄金属鉱山の維持は, 品位の低下, 高貨金, 職場環 境の悪化などにより，今後ますます困難になることが容 易に想像される。

国内鉱山産出の銅量は1992年で7.5千トン，自給率は $0.5 \%$ となった。一方, 海外鉱石の翰入は需要の増大に 伴って年々増加し，1992年には1,053千トンで海外依存 度は99.5\%となっている。亜鉛, 鉛も同様な傾向で, 1992年は139.1千トン（自給率18.8\%）と28.5千トン（自 給率10.8\%）で，海外鉱石の翰入は亜鈶が498.6千トン, 鈆は188.4千トンである。

\section{3. 日本の海外鉱山開発の現状}

\section{1 海外鉱山開発の意菜と必要性}

1992年, 日本の非鉄金属の生産と消費 ${ }^{10)}$ は銅で世界 第 3 位（1,160.9千トンで10.5\%）と 2 位（1,411.1千ト ソで12.7\%)，亜鉛で第 1 位（729.5千トンで10.6\%）と 2 位（783.7千トンで12.0\%)，鈶は第 5 位（330.2千トン で6.2\%）と 3 位（401.9千トンで7.9\%）であり，海外 鉱山開発は国家的立場から次のような必要性と意義を持 っている ${ }^{9)} 。$

(1)資源の安定確保。

(2)資源消費国として世界経済に対する責務。

(3)資源保有国（発展途上国）への経済協力。

また, 円高環境下で生残るための企業の立場からは次 の点が指摘される。

(1)強い円による投資効果 (円高の有効利用)。 (2)製鎮業の維持とアジアでの市場コントロール。 (3)鉣山・製錪事業の一体化による収益の改善。

\section{2 海外鉣石確保の経緯9)}


海外鉱石の確保には次の 3 つの方法がある。

(1)単純買鉱：短期および長期的貿易取引。

(2)融資買鉱：鉱山開発資金を融資し，鉱石の長期的か つ安定的引取。

(3)自主開発：日本企業の資本・経営主導による鉱山開 発（最近の傾向として，開発投資的な非鉄メジャ一 の鉱山開発にマイナーシェアーでの資本参加が目立 つ)。

1940年代後半は国内鉱山の実力もあり, 不足分を単純 買鉱により確保していた。しかし，1950年代前半から非 鉄金属の需要が急激に伸び, 翰入鉱石の長期安定化扣よ び低価格化を求め, 融資買鉱が行われるようになった。 それらの例にはフィリピンのトレド鉱山（1953年，融資 44億円)，バガカイ鉱山（1954年），シパライ鉱山（1955 年）などがある。1965年には日本企業共同（J/V 方式） による大型融資買鉱契約（115億円）がリオブランコ鉱 山（チリ）で実現し，この $\mathrm{J} / \mathrm{V}$ 方式はその後の，商社 も参加した融資買鉱のひな型となった。

自主開発はリスク負担が大きいが，探鉱から開発・操 業まで日本企業が行い, 安い鉱石を長期に確保しょうと するもので, 1957年の小規模なポルテスエロ鉱山（チリ） 開発が最初の成功例である。1962年に海外鉱物資源開発 株式会社の設立, 1968年には金属鉱業事業団に海外業務 が追加され，国による積極的な海外鉱山開発支援体制が 確立した。1966年に利権を獲得したムソシ銅鉱山開発(ザ イール)や, 1967年のマムート銅鈗山開発（マレーシア） は大型自主開発鉱山の事例であるが，1960年代に始まっ た資源ナショナリズムにより，資本比率の制限やロイヤ ルティーなどの諸条件が厳しく，また，1974年の石油危 機, その後の円高基調による建設費の高勝, さらに長期 間の銅価格低迷の影響で，両鉱山は一時期大きな損失を 計上した。この間，日本の非鉄企業は国内鉱山の閉山に よる多大な損失を抱え, 以後の大型自主開発は低迷時期 に入った。これは海外探鉱開発費の推移8)に現れており， $1976 \sim 1980$ 年の 5 年間の年平均探鉱費 75 億円, 開発費 156億円が，1986～1990年には探鉱費20億円，開発費25 億円へと減少している。

\section{3 海外鉱山開発の現状 ${ }^{10)}$}

1992年の日本の銅の形態別国別の翰入量は，鉙石が 983.3千トン（地金換算）で，その内訳は単純買鉱が $52 \%$, 融資買鉱が $43 \%$, 自主開発 $5 \%$ であり, ブリスター

（30.9千トン）と地金（369.8千トン）も合計した国別 翰入量（合計 1384.0 千トン）は, チリ $25.1 \%$ ，カナダ $17.3 \%$ ，インドネシア $10.6 \%$ ，米国9.0\%，フィリピン $8.7 \%$, ザンビア $6.1 \%$ ，パプア・ニューギ=ア5.4\%, ペルー5.0\%, オーストラリア $4.3 \%$, マレーシア $2.1 \%$, その他 $6.4 \%$ となっている。
第 1 表 日本企業の主な海外銅鉱山開発 ${ }^{10}$

\begin{tabular}{|c|c|c|c|c|c|c|}
\hline 选山名 & Northparkes & Morenci & Chino & La Escondida & El Roble & La Candelaria \\
\hline 柆加形宫 & 绿釛国発 & 尔本参加 & 家本经加 & 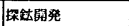 & 探制開琵 & 探釹開発 \\
\hline 国名 & $x-$-2k케 & & & & $200 \boldsymbol{K}^{*}$ & $\neq 11$ \\
\hline 日本企怶 & 住友,住商 & 住友，住商 & 三荌，商列 & 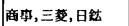 & 日鉄，伊萼忠 & 住友, 住商 \\
\hline 主要相手企菜 & NBHP(80\%) & PD(85\%) & $\mathrm{PD}(2 / 3)$ & $\operatorname{BHP}(60 \%), \operatorname{RTZ}(30 \%)$ & HERR(51\%) & PD (80\%) \\
\hline 生産针口 & $48 \mp ト /$ 年 & 310干ド/年 & $133 \mp \% /$ 年 & 316 千 & $3 千 r$ /年 & 120干ト/年 \\
\hline 短䦎発口回 & 240 百万品 $k^{*} \%$ & & & 850 百万ト & 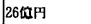 & 559 百万ト \\
\hline 日本构負担 & & 75 百万ド & & 41 百万ド & $26 \mathrm{WP}$ & \\
\hline & 63百万兹卜・゙ & & 58 百万ド & 27百万ド & 10䇱円 & 91 百万ド \\
\hline 開然開始 & 1993/4 & & & 1988/8 & $1986 / 9$ & $1993 / 4$ \\
\hline 生産開始 & $1995 / 9$ & 招叒(1942) & 投莱(1909) & 捺荣(1991/1) & 探粟(1991/1) & $1995 / 1$ \\
\hline
\end{tabular}

1993年10月末現在の日本企業が関与している海外銅鉱 山開発は, 探鉱中 2 件 (チリ, パプア・ニューギニア),

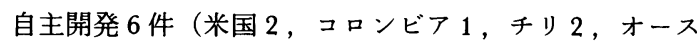
トラリア 1)，融資買鉱 9 件の合計17件である。主要な 銅鉱山開発の概要は第 1 表に示す。

\section{4. 海外鉱山開発の問題点 ${ }^{9)}$}

海外での鉱山開発には, 次のような諸問題が考えられ る。

（1）資源賦存の偏在性

資源の賦存状況は，米国，カナダおよび豪州を除くと 先進国には少なく，発展途上国に偏在しており，高い力 ントリー・リスクを伴ら鉱山開発となる。しかし，近年， 国営鉱業の民営化および鉱業の自由化政策により，外国 資本と新技術を導入して, 鉱業の近代化を進める国々( リ，ペルー，アルゼンチン，メキシコなど）が多くなり つつあり, 今後もこの傾向は続くものと思われる。

（2）鉱山開発のリードタイム

探鉣から開発・生産まで, 鉣山開発には長期間の（約 10〜15年）リードタイムが必要であり，その間の不測事 態（政変, 経済変動, 鉱床規模の変化）によるリスク増 大が一般的である。

（3）探鉱の不確実性とリスク

鉱山開発に結びつく探鉱の確率は非常に低く，事業と してリスクが大きい。また，事業規模や収益の見通しも 金属価格に左右される。

（4）探鉣・開発条件および経験の差

長期的戦略に基づき探鉣・開発を実施して，優良な既 存利権を押さえ，かつ経験豊富で情報網の充実した欧米 の非鉄メジャーに比べて, 日本企業は条件の悪い探鉱・ 開発を実施せざるをえない実状にある。

（5）大規模な投資

山間僻地にある鉣山開発はインフラストラクチャーの 整備を含め, リスクを伴う巨大な資金を必要とするが， 非鉄メジャ一は膨大な資金と豊富な内部留保を有してい る。日本企業は最近の円高によるメリットがあるものの， それぞれのスケールはいかにも小さい。 


\section{5. 非鉄メジャ一の戦略1),2),4),6),7)}

\section{1 非鉄メジャ一の䅉向}

現在，非鉄メジャ一は高い金属価格と優良鉱山の操業 などで高収益を上げているが，過去に 2 回の危機があっ た。最初は1960年代の資源ナショナリズムの台頭であっ た。1960年代初め，国営企業の銅生産は自由世界で $2.5 \%$ 程度であったが，ザイール，ザンビア，チリ，ペ ルーなどでの国有化により，1980年代初めには30\%を越 えるようになった。

一方，1970年代は石油メジャ一の銅鉱山の買収時期で あった。1973年の石油危機に伴う石油価格の高騰により， 石油メジャ一は巨大な利益を獲得し，その投資先として 銅鉱山を選択した。こうして，米国銅鉱山が次々に買収 され，1981年には米国の銅生産の60\%を支配するように なった。しかし，1982～1986年は銅価格の長期低迷時期 でもあり，また，1983年からは石油価格の低迷が始まっ たため，銅鉱山からの撤退を余儀なくされ，1984年に Texaco が Escondida の50\%権益の売却（BHP10\%， RTZ30\%，JECO10\%で買収）もその事例であり，1986 年の石油メジャ一の米国銅生産は $18 \%$ ，自由世界の $5 \%$ へと激減した。最近も石油メジャーのコアビジネス回帰 の傾向は続いており，1989年 6 月の RTZ による BP Minerals（British Petroleum の子会社）の43億ドルでの 買収，1992年10月の Shevron が所有する Collahuasi 銅プ ロジェクト（チリ）の $33.3 \% の$ 利権を, Anglo American
（南ア）が190百万ドルで買収，1994年 7 月には Gencor （南ア）が Billiton（Shell の金属部門の子会社）を12億ド ルで買収したとの報道があった。

この間，米国名門企業の Anaconda や Kennecott の没 落, Amax や Newmont の上うに銅鉱業から撤退した非 鉄メジャ一もあったが，大幅な合理化と多角化により生 延びた非鉄メジャーは, 近年, 大規模な買収・合併を通 して活発な資源戦略を展開している。

1990～1992年の非鉄メジャーの経営権に基づく支配比 率による世界の順位は第 2 表に示すが，1992年の推定で は，AAC が依然として第 1 位（支配率7.7\%），第 2 位 は RTZ（同5.2\%）で，急上昇の民間企業は BHP（第4 位, 2.5\%), Gencor（第 6 位, 1.6\%), Freeport（第 7 位, 1.4\%)，IMCERA（第 8 位，1.4\%）などがあり, 国営 企業ではブラジル（第 3 位， $3.3 \% ）$ やリ（第 5 位, 2.3\%）が上位にいる。

1990年での銅生産に基づく非鉄メジャ一の世界ランキ ングは第 3 表に示す通り，第 1 位はチリの国営企業であ る CODELCO (17.1\%), 次いで Phelps Dodge (8.2\%), RTZ (6.5\%), Asarco (5.7\%), AAC (5.0\%) の順にな っている。

\section{2 非鉄メジャ一の戦略}

(1) 垂直的統合の強化

Asarco はもともと製錬業を中心としたカスタムスメ ルターであったが，銅価格低迷時における戦略として， 製錬施設の近代化や拡張によるコスト削减に加え，川上

第 2 表 世界の非鉄メジャ一の鈗業支配率4)

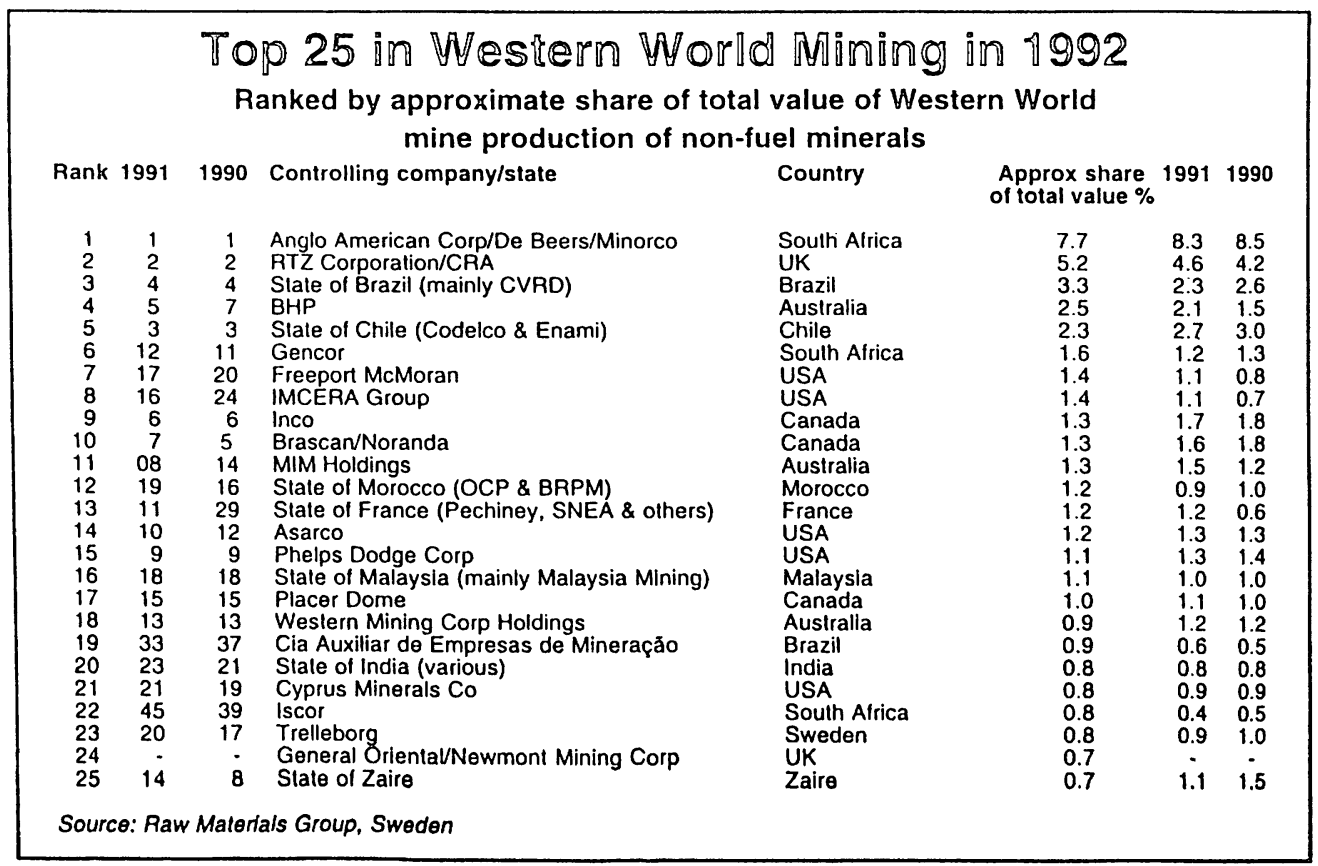


第 3 表 世界の非鉄メジャ一の銅生産 $\left.(1990)^{7}\right)$

\begin{tabular}{|l|l|l|l|l|}
\hline Rank & Company/State & Country & $\begin{array}{l}\text { Copper } \\
(\mathrm{Kt})\end{array}$ & $\begin{array}{l}\text { Share } \\
(\%)\end{array}$ \\
\hline 1 & CODELCO(+ENAMI) & Chile & 1226.5 & 17.1 \\
2 & Phelps Dodge Corp & USA & 585.7 & 8.2 \\
3 & RTZ Corp. & UK & 469.7 & 6.5 \\
4 & Asarco Inc. & USA & 410.9 & 5.7 \\
5 & Anglo American & South Africa & 361.7 & 5.0 \\
6 & GECAMINES & Zaire & 355.4 & 5.0 \\
7 & ZCCM & Zambia & 316.5 & 4.4 \\
8 & Cyprus Minerals & USA & 290.3 & 4.0 \\
9 & Brascan/Noranda & Canada & 223.6 & 3.1 \\
10 & Magma Copper Co & USA & 211.7 & 3.0 \\
\hline
\end{tabular}

部門の鉱山を含めた垂直統合化を進めた。1986年に Kennecott からの Ray 鉱山買収や Mission Complex での 生産拠点確立はその一環であった。

（2）銅生産コストの削減

Phelps Dodge は SX-EW 法の推進によるコスト削減を 進め, 設備投資の資金確保として, (1)長期借入金の利用, (2)労務費や管理費の削減と不採算鉱山の閉鎖, (3)資産の 売却（Morenci 鉱山の権益15\%を住友グループに売却） を実施した。また，Kennecott から Chino 鉱山の 2/3の 権益を買収し, Morenci, Tyrone, Chino の 3 大鉱山を背 景に米国最大の産銅企業となった。

( 3 ）多角化

RTZ は工業・鉱業・エネルギーの 3 分野のらち, 工 業部門を重視した継続的払大を図るとともに，鉱業部門 では合理化を含む選択的払大を目指した。大型㑑良鉱山 の開発(チリの Escondida やポルトガルの Neves-Corvo) や1989年 6 月の43億ドルでの BP Minerals の買収がそれ である。

（4）買収・合併

AAC や Gencorなどの南アの企業は, 国内の政治的問 題から資産の海外への分散を目的として，前述のように 買収や投資を積極的に進めている。また，1993年12月の Cyprus と Amax の大型合併は企業体質の強化（多角化） を目的としたもので，世界で10位以内に入る企業となっ た。この買収・合併は今後も各企業間で積極的に行われ ると予想され，世界の非鉄金属資源は巨大な資金力を背 景にした非鉄メジャーによる頞占化が進行しつつある。

（5）国営企業の民営化拉よび鉱業の自由化政策

発展途上国は1960年代からの資源ナショナリズムの興 隆により，相次いで非鉄メジャ一の鉱山を国有化し， CODELCO (チリ), ZCCM (ザンビア), GECAMINES (ザイール), Minero Peru (ペルー) など の国営企業を設立した。しかし，その後の資金不足によ
る新規投資の停帯は，鉱山および施設の老朽化によるコ スト増を招き，次第にその競争力を低下していった。こ のため, 発展途上国は近年, 経済開放と鉱業の自由化へ その政策を転換しつつある。これは外国資本を導入し， 国の基幹産業である鉱業の活発化を図り，既存鉱山への 設備投資や新技術の導入および新規鉱山の開発を促進し ようとするものである。民営化としてペルーの Minero Peru や Centromin, 鉱業の自由化としてチリの El Abra や Radomiro Tomic 銅鉱床 (CODELCO 所有)，アルゼ ンチンの Bajo De La Alumbrera 銅鉱床（YMAD 所有） などがあり，国際入札のため，非鉄メジャーが大資本を 背景に積極的に参加・買収しているのが現状である。

（6）大規模銅鉱山の拡張計画

特に注目すべき拡張計画には，チリの Escondida 鉱山 とインドネシアの Ertsberg 鉱山がある。Escondida 鉱山 は BHP57.5\%, RTZ30\%, JECO10\%, IFC2.5\%の資本構 成で，1993年に銅生産36万トンであったが，1996年から 80万トンになる予定で, CODELCO の Chuquicamata 鉱山（1993年の銅生産62.8万トン）を抜いて世界第 1 位 になる。Ertsberg 鉱山は Freeport Indonesia により操業 され，1992年の銅生産は29万トンであったが，1996年か らは50万トンになる計画である。両鉱山は世界で第 1 ， 2 位の大規模操業（世界の銅生産の $18 \%$ 相当）となり, 両社の銅生産の規模も Phelps Dodge や RTZ と同程度あ るいはそれ以上となる。

\section{6. 世界の主要銅鉱山と新規銅鉱山開発}

\section{1 主要な銅鉱山と新規開発}

主要な銅鉱山は第 4 表に，また，第 5 表には2000年ま でに開発が予定されている大型銅鉣山開発を示す。いず れもチリに大規模操業および開発が集中している。

\section{2 最近の銅鉱山開発の傾向 ${ }^{3), 5)}$}

最近の銅鉱山開発は大型化かつ起業費の巨大化傾向に ある。第 5 表に示すように年産銅量十数万トン〜数十万 トンで，その起業費は300〜1,000百万ドルにも達し，リ スク分散や資金調達のため, 非鉄メジャ一間での $\mathrm{J} / \mathrm{V}$ および国際金融機関（IFCなど）の参加を求める傾向が

第 4 表 世界の主要な銅鉱山と生産量 (1992)

\begin{tabular}{|l|l|l|l|l|l|l|}
\hline Rank & Copper Mine & Conpany/State & Country & Operation & Cu(Kt) & Expansion \\
\hline 1 & Chuquicamata & CODELCO & Chile & 1915 & 628 & \\
2 & La Escondida & BHP/RTZ/JEC0/IFC & Chile & 1991 & 316 & 800Kt(1996) \\
3 & El Teniente & CODELCO & Chile & 1904 & 314 & \\
4 & Morenci & PD/SMMA & USA & 1942 & 310 & 400Kt(1996) \\
5 & Ertsberg & Freeport & Indonesia & 1973 & 291 & $500 \mathrm{Kt}(1996)$ \\
6 & Bingham Canyon & Kennecott & USA & 1903 & 289 & \\
7 & Ok Tedi & BHP/Anoco/PNG & PNG & 1987 & 193 & \\
8 & Nchanga & CCCM & Zanbia & 1927 & 179 & \\
9 & Highland Valley & Coninco/RTZ/Teck & Canada & 1972 & 171 & \\
10 & Mount Isa & MIM & Australia & 1931 & 171 & \\
\hline
\end{tabular}


第 5 表 世界の主要な銅鉱山開発

\begin{tabular}{|c|c|c|c|c|c|c|c|c|c|}
\hline Copper Project & Country & Company/State & $\begin{array}{l}\text { Cost } \\
\text { (US\$ M) }\end{array}$ & $\begin{array}{l}\text { Capacity } \\
\text { (Kt) }\end{array}$ & $\begin{array}{l}\text { Date of } \\
\text { Sale }\end{array}$ & $\begin{array}{l}\text { Percent } \\
\text { Bought } \\
\text { or Sold } \\
\end{array}$ & Buyer & Seller & \begin{tabular}{|l} 
Purchase \\
Price \\
(US\$ M)
\end{tabular} \\
\hline Collahuasi & Chile & Falconbridge, AAC, Shell(1/3) & 1,000 & 350 & $12 / 92$ & 33.3 & AAC & Chevron & 190 \\
\hline El Abra & Chile & Cyprus $51 \%$, CODELC049\% & 1,000 & 225 & $6 / 94$ & 51 & Cyprus & CODELCO & 330 \\
\hline Salobo & Brazil & CVRD50\%, AAC50\% & 750 & 200 & & & & & \\
\hline Bajo De La Alumbrera & Argentine & Musto50\%, MIM50\% & 500 & 127 & $2 / 94$ & 50 & MIM & Musto & 130 \\
\hline Radomiro Tomic & Chile & CODELCO & 450 & 150 & & & & & \\
\hline Zaldivar & Chile & Outokumpu50\%,Placer Dome $50 \%$ & 600 & 125 & $12 / 92$ & 50 & Placer I & Outokumpu & 100 \\
\hline Quebrada Blanca & Chile & Cominco\&Teck76.5\% & 360 & 75 & & & & & \\
\hline Cerro Verde & Peru & Cyprus & 375 & 115 & $11 / 93$ & 100 & Cyprus & Minero Peru & 37 \\
\hline Quellaveco & Peru & AAC & 550 & 120 & $12 / 92$ & 100 & AAC & Minero Peru & 12 \\
\hline
\end{tabular}

ある。

また，榎良な大型銅鉱山開発は当事者間の単独交渉よ りも, 国際入札による競争原理導入が一般化し, 経験豊 富で資金力のある非鉄メジャ一に有利な状況である。さ らに，参入費（または買収費）の高騰が顕著で，参入シ ×ア $1 \%$ 当り $3 \sim 7$ 百万ドルの場合もある (第 5 表)。 これは金属価格が好調なこと，発展途上国の政治的，経 済的リスクが軽減されつつあること，外国資本に対し俓 遇策を考虑していること，非鉄メジャ一が好調な業績を 背景に積極的な投資を実施していることなどに関連して いる。

\section{7.おわりに}

\section{（日本企業の海外銅鉱山開発への戦略）}

日本の海外銅鉱山開発への参画は既に述べたように, 世界の大地金生産国および消費国として，円高環境下で の非鉄産業の維持および事業の収益向上のために不可欠 と言えよう。

世界の非鉄メジャ一の市場寡占化，参入費や起業費の 巨大化の傾向が進む中で，消極的な態度では激動する世 界の非鉄資源界の潮流から取残されてしまう。日常から 積極的に非鉄メジャ一との関係を構筑し, 情報の收集と 世界の傾向を把握しておく必要がある。そして既存鉱山 や鉱山開発の資本参加のため，単独あるいは非鉄メジ ャ一との共同での国際入札の参加が望まれるところであ る。

大型開発参加の場合， $10 \%$ 程度の資本参加でも，参入 費は20〜70百万ドルにもなり，起業費の負担を考えれば， 総額50〜150百万ドルにもなる。従って，リスクや資金 の相互負担の意味からも企業共同（J/V 方式）での参加 形態が採用される。大型開発へ単独で参加する時代は過 き，外国企業との $\mathrm{J} / \mathrm{V}$ は勿論のこと，日本の非鉄企業 の共同，さらに商社などの参加も加味した日本グループ としての形態も考感されるだろう。

比較的規模の小さい開発では，地元資本との $\mathrm{J} / \mathrm{V}$ で
の形態が考えられる。また，金属鉱業事業団などの各種 支援体制を活用して，探鉱から開発・操業まで一貫した 鉱山開発を, 日本の資本・経営主導のもとに実施するこ ともできる。この最近の成功例には, El Roble 銅鉱山( ロンビフ）や Tizapa 鉛亜鈆鉱山（メキシコ）などがあ る。

鉱山開発は一般的に山間僻地があり，道路，鉄道，港 湾, 発電, 住宅などのインフラストラクチャ一の整備が 必要な場合が多い。過去にインフラのコスト高のために 経済性がないと破棄された鉱山開発が，その後の周辺部 でのインフラ整備に伴って，経済性が見直される場合も 出てきている。発展途上国での鉱山開発に伴らインフラ 整備は, 同時に地域社会の経済活動を活発化する働きも ある訳で，ODA などの国の支援制度も活用したいとこ ろである。

\section{謝辞}

早稲田大学理工学部原田種臣教授には, 本学会での発 表の機会を与えていただき，厚く感謝致します。

\section{参 考 文 献}

1）金属鉱業事業団，非鉄メジャ一の動向（1），1１43 (1989)

2）金属鉱業事業団，非鉄メジャ一の動向（2），1～54 (1990)

3) Metals Finance, No. 2, 2 (1994)

4) Metals Finance, No. 3, 6 (1994)

5) Metal Economics Group, Strategic Report March/April 1993, Vol. 6, 1 10 (1993)

6）日本メタル経済研究所，主要産銅企業からみた銅供 給構造の変化, $1 \sim 69(1990)$

7) Raw Materials Group, Who owns who in mining 1992, 1 327 (1992)

8）資源エネルギー庁釷業課編，非鉄金属製錬業の展開 と海外鉱山開発の推進, $1 \sim 154(1994)$

9）通産資料調査会，資源エネルギー年間1993， 19 103 (1992)

10）通産産業調査会，鉱業便覧平成 6 年版，1２34 (1994) 